\title{
Comparative study of sustainable drainage systems
}

1 Jonathan Hubert BSC

PhD Student, Department of the Built Environment, University of West London, London, UK

2. Thomas Edwards BEng

Project Engineer, Civil \& Infrastructure, AKS Ward Ltd, Oxford, UK
3 Ali Bahadori Jahromi MSc, PhD, CEng, MICE

Senior Lecturer, Department of the Built Environment, University of West London, London, UK
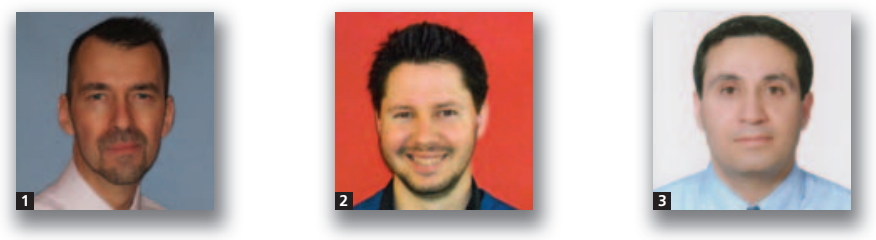

The use of sustainable drainage systems (Suds) forms an important part of the requirement to conserve natural resources in an age of ever-increasing consumption. This paper explores the options available in the design of drainage systems, by virtue of a project to design two systems for a greenfield site with office and car parking. One design is a conventional piped setup and the other is a 'sustainable' drainage system. The design approach is not biased towards the conventional or sustainable system, but aims to seek out best practice in terms of economics and simplicity of design for each type. This computer-based software simulation study of the two drainage systems includes an introduction to Suds, with a description of the principles and techniques involved. There is further information on who is driving the requirements for implementation and the methods used to do so. This background will then inform the comparative study of drainage system designs.

\section{The need for sustainable drainage systems (Suds)}

The removal of surface water from a given location is the principal issue with conventional drainage systems: specifically, the speed at which surface water is drained from a developed site. In many places this happens too quickly, over-extending the capacity of both natural and man-made drainage systems to absorb the volume of water. According to Woods Ballard et al. (2007), building on virgin ground

may reduce the permeability of the land surface by replacing free draining ground with impermeable roofs, roads and paved areas that are drained by pipe or channel systems. Clearing of the area removes the natural vegetation that intercepts, slows and returns rainfall to the air through evapotranspiration.

This issue applies to already developed sites; while demand exceeds supply for all types of accommodation, there will always be pressure to build more and at increased densities in urban locations. Where there is little or no natural drainage, heavy rainfall will result in near $100 \%$ runoff to conventional piped systems, causing downstream flooding and a sudden rise in flow rates and water levels in adjacent watercourses. A further complication of surface water runoff is the level of toxic and other potentially harmful substances that flush into said rivers and waterways. Although each occurrence may be minimal, over time, the build-up of chemicals can cause harm to these areas, instead of being dispersed naturally had a 'freedraining' site been available. The impact on smaller rivers and streams can be severe: organic matter reduces oxygen levels in the water, while high levels of silt blanket all life in the waterway.

Habitat around rivers and watercourses can change for two reasons: high flow rates for a short time or prolonged periods with reduced water flow. Riverbeds and banks are eroded by higher flow rates, with the material deposited downstream. The building of culverts to control erosion and divert natural water routes serves mostly to reduce available habitat for a variety of flora and fauna and often creates an eyesore in the process.

\section{The Suds approach}

The principal idea of sustainable urban drainage systems (Suds) is to mimic as closely as possible the natural drainage 
from a site prior to development and to remove pollutants from the runoff. This concept offers many options for draining a site, giving the designer a deal of flexibility in the means used to create a system to suit a particular location.

Although each site will need a custom solution, the designer must consider the core principles of Suds: water quality, water quantity and amenity, and biodiversity (Ciria, 2000: p. 2). Ideally, these design criteria should be agreed upon by all stakeholders in the scheme being devised, as noted in Section 3. The designer and client, at least, should have an understanding of what outcomes are expected from the scheme.

The Suds approach includes a range of components, from soakaways to ponds, which need to be used in such a way that they follow the natural pattern of drainage at each location. This pattern has been classified by the Construction Industry Research and Information Association (Ciria) into a 'hierarchy of techniques' used 'in series to incrementally reduce pollution, flow rates and volumes' (Woods Ballard et al., 2007). There are parallels here with the 'hierarchy of waste' - a common method of defining the various stages of reducing the amount of manmade materials that go to landfill. This too emphasises prevention at the top of the hierarchy, moving through various stages that impose a progressively greater burden on natural and human resources. The Suds hierarchy, however, is more obviously geographic - specifying measures by stage that increase the area involved. This hierarchy, referred to as a 'surface water management train' by Ciria, comprises four stages

$$
\begin{aligned}
& \text { prevention } \\
& \text { source control } \\
& \text { site control } \\
& \text { regional control. }
\end{aligned}
$$

To prevent runoff and pollution in the first place requires the integration of Suds into an overall design for any given development site. No part of the building(s), external amenities or landscaping can be designed in isolation (May and Kellagher, 2004). Minimising paved areas and sweeping surface debris from car parks represent two types of prevention; if this is not possible, controlling runoff close to the source is the next best option. Ways and means of doing this include rainwater harvesting, green roofs, soakaways and pervious pavement. The next step up in scale involves the entire development site, where the flow of water is controlled by routing excess amounts from roofs and car parks to a single soakaway or infiltration basin designed for the whole site. Regional control of drainage expands this control by managing runoff from several locations, making use of semi-natural features such as detention ponds or naturally occurring wetlands. The overarching provision in the management train is that 'water should be conveyed elsewhere only if it cannot be dealt with on site' (Woods Ballard et al., 2007).

\section{Benefits of Suds}

Using Suds in new construction is part of a larger planning policy to extract benefits - both tangible and intangible - from sustainable methods of development. After much of the twentieth century allowed building with little thought to conservation of habitat, the first UK biodiversity report recognised that (UK Government, 1994: p. 25)

Restoration of biodiversity is time-consuming and expensive; what is easy to lose quickly is hard to regain, even slowly.

Subsequent planning policies (ODPM, 2005: p. 2) have made sustainability and amenity the key element in virtually all new development, in terms of

biodiversity in green spaces and among developments so that they are used by wildlife and valued by people, recognising that healthy functional ecosystems can contribute to a better quality of life.

The priority when considering Suds is local input - in other words, the people living and working in the area who will be affected by it. Conventional piped drainage systems have been in use for generations and people are used to 'out of sight, out of mind' when thinking about drainage systems, if they think about them at all. There is a step-change required when introducing sustainable concepts such as large-scale soakaways or infiltration basins.

The National Suds Working Group (NSWG) (comprising members from both public and private bodies) formed under the aegis of the Department for Environment, Food and Rural Affairs (Defra) frames the benefits of Suds in design terms, whereas the Environment Agency (government employees only, reporting to Defra) lays out the advantages of Suds in broader terms, more accessible to people who may be affected by a new Suds scheme. An example of the difference in approach can be gleaned from the following, describing how Suds can benefit the local environment.

Improving water quality over conventional surface water sewers by removing pollutants from diffuse pollutant sources (NSWG, 2004)

Suds can protect watercourses from pollution caused by accidental spillages and misconnections (Environment Agency, 2003)

The Environment Agency and the NSWG both desire the same thing: acceptance of Suds as a 'normal' method of controlling the flow and volume of surface water from developed sites, leading to a reduction in flood risk and improvement of natural amenities for both public spaces and wildlife habitat. 


\section{Legislation and guidance for Suds in the UK}

Acts of Parliament involving Suds are regulated by two bodies in the UK: the Environment Agency, a department of Defra, is responsible for England, Wales and Northern Ireland (under the auspices of the NI Environment Agency), while Scotland has a separate body, the Scottish Environment Protection Agency (SEPA).

There are six major pieces of legislation and/or policies that affect the use of Suds in England (and some in Wales). These are

- Planning Policy Statement 25: Development and Flood Risk (PPS25) (DCLG, 2006)

- Building Regulations Approved Document H (ODPM, 2002)

- European Union water framework directive (European Union, 2000)

- Flood and Water Management Act 2010 (2010)

- Pollution Prevention Guidelines 3 (PPG3) (Environment Agency, 2006a)

- The Code for Sustainable Homes

- Sewers for Adoption, 6th edition (WRc plc, 2006)

The equivalent legislation for PPS25 in Scotland is Scottish Planning Policy 7: Planning and Flooding (SPP7), while the Welsh Assembly produces its own version in Technical Advice Note 15: Development and Flood Risk (TAN15). The principal difference in these policies concerns the assessment of flood risk, with Scotland keeping a more stringent standard in place (Jones, 2008). Likewise the Scottish equivalent for Approved Document $\mathrm{H}$ is Technical Handbook 3, which includes a specific section on Suds and their application.

The area of Suds that concerns (or indeed should concern) most people is the risk of flooding to homes and businesses. The effects can be devastating, as anyone witnessing the events in and around Tewkesbury, Gloucestershire, in 2007 could testify (Figure 1). Although government policy favours brownfield construction, there are inevitably districts where building on previously undeveloped land is needed. Using conventional piped systems to transfer surface water away from these areas increases the risk of flooding downstream due to the unnatural flow rates generated.

PPS25 (DCLG, 2006) (revised in 2010) is a policy statement on development and flood risk from the Department for Communities and Local Government (DCLG), which requires the use of Suds techniques to minimise risk of flooding downstream from new developments. Any new site with an area of 1 ha or more has to have a flood risk assessment as part of the planning application. The Environment Agency is the

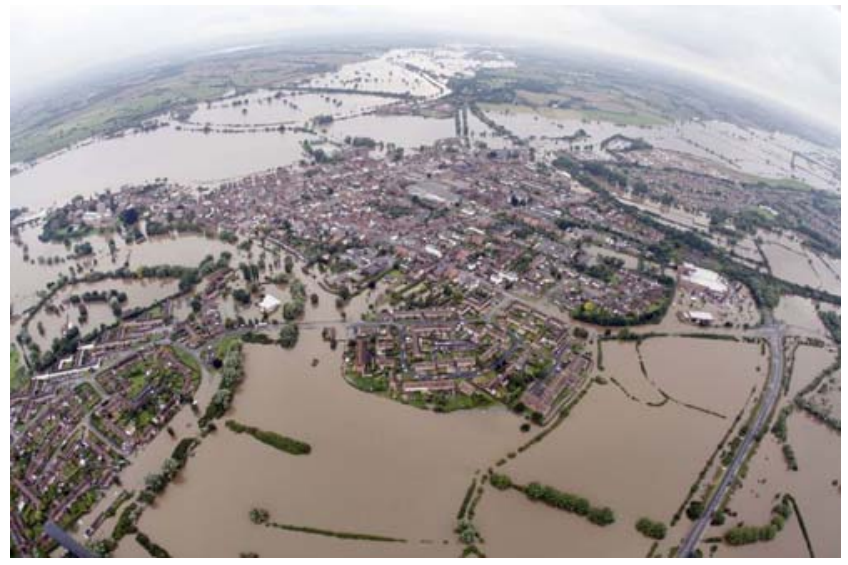

Figure 1. Tewkesbury borough floods 2007

(http://www.tewkesbury.gov.uk/index.cf marticleid=3436)

statutory authority in England and Wales and will request planning conditions that include the use of Suds as the default option, rather than the other way around. The sixth edition of Sewers for Adoption makes allowance for the water companies to maintain Suds systems as sewers on public property, subject to certain conditions (WRc plc, 2006).

Virtually all aspects of building in the UK have some form of regulation associated with them: drainage is no exception, being covered (in England) by the Building Regulations Approved Document H: Drainage and waste disposal. The latest edition (ODPM, 2002) includes the following hierarchy for Suds.

Rainwater... shall discharge to one of the following, listed in order of priority:

(a) an adequate soakaway or some other adequate infiltration system; or...

(b) a watercourse; or...

(c) a sewer.

The conventional piped sewer is listed a last resort. Recent legislation in the UK has been drafted to incorporate European Union law, specifically directive 2000/60/EC of October 2000 known as the water framework directive (European Union, 2000). The principal aims of this framework are based on the premise that

Water is not a commercial product like any other but, rather, a heritage which must be protected, defended and treated as such.

Hence the emphasis is on protection of aquatic ecosystems, sustainable water use and reduction of pollution levels, floods and droughts. The Flood and Water Management Act of 2010 devotes an entire section (Schedule 3) to sustainable drainage, 
essentially adopting the water framework directive into UK legislation. The priority now assigned to means of drainage can be gauged by the specific wording in the Act, laying the responsibility for proper use of resources with a local 'approving body'; although this would ordinarily be the local council/unitary authority, the government minister responsible has the power to appoint a separate body if this is deemed necessary. Schedule 3 'Requirement for approval' states

Construction work which has drainage implications may not be commenced unless a drainage system for the work has been approved by the approving body.

Document PPG3 (Environment Agency, 2006a) is one of a series of pollution prevention guidelines produced by the Environment Agency; this one covers the use and design of oil separators in surface water drainage systems. Most commonly used where a car park is needed as part of development design (the majority of sites), PPG3 specifies how to best prevent the leakage of oil and fuel into watercourses and groundwater generally. A conventional system usually has an oil separator tank installed to trap pollutants, requiring scheduled manual emptying. The guidance now allows proven Suds techniques to accomplish the same thing.

\section{Suds techniques}

There are a number of methods available to reduce surface water runoff, either standalone or in combination.

Infiltration trenches. These are stone-filled reservoirs, used to collect stormwater runoff, which then allow the contents to seep gradually into the ground. Any large solids are captured at the inflow by a filter strip, gully or sump pit. The absorption and filtering capabilities of the surrounding soil are used to remove pollutants.

- Permeable pavements. Materials such as concrete blocks, crushed stone or porous asphalt can be used to construct a porous but hardstanding surface for footpaths and car parking. This reduces or even eliminates the need for drains and off-site sewers when water can infiltrate directly into the subsoil, or at least into a reservoir such as a crushed stone layer before soaking in.

- Swales and basins. Rather than adding materials to a feature, swales are notable for their simplicity: they are 'manufactured' grass depressions, contoured to route surface water away from a drained surface to a means of storage or discharge. A basin is similar, but used to hold back stormwater runoff, allow solids to settle out of the water and provide some water infiltration directly into the ground.

- Ponds and wetlands. These represent one of the most marketable aspects of sustainable drainage design: landscape features that enhance the visual amenity of any newly developed area, often pictured on the front of brochures for new housing or commercial sites, while contributing immensely to the natural environment. Ponds or wetlands can handle large variations in water levels during a storm, enhancing flood storage capacity, and algae and plants provide the best method of filtering and nutrient removal. Both conventional piped systems and natural swales can feed ponds and wetland areas.

\subsection{Custom solutions}

The case study comparison uses the standard methods listed above; each project would make use of bespoke solutions that fit with the site conditions and aesthetics. The Suds techniques discussed in this document are only relevant to techniques used and compared; this document does not seek to give detailed descriptions of all techniques available as there are many publications which serve this purpose, such as the Ciria Suds manual (Woods Ballard et al., 2007).

\subsection{Green roofs and rainwater reuse}

The use of 'green' roofs and the reuse of rainwater or 'rainwater harvesting' are complementary techniques to Suds. Both options reduce the peak flow rates and volume of water runoff and are included here as they are arguably two of the first 'eco-sustainable' solutions that come to mind. Further details are not included since they can be used in both types of system and do not add to the comparison of drainage systems investigated in this paper.

\section{Pre-design considerations}

Before detailed design work on the two drainage systems for this case study can begin, a comprehensive site investigation is required. A basic list of items to consider when preparing drainage designs includes

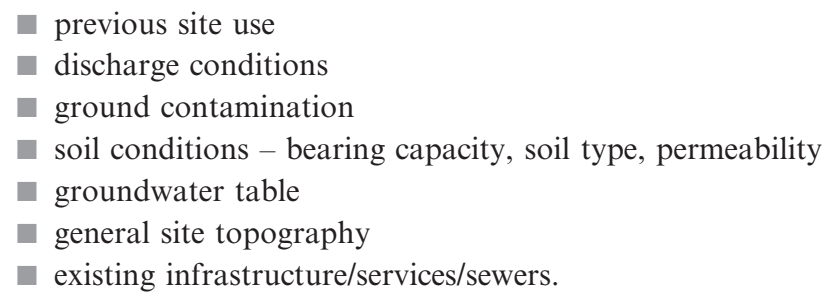

Using data available from the Environment Agency (2006b), a flood zone check should be carried out to determine the likelihood of flooding and what effects the development would have on any local flooding issues.

The site chosen for this study has never been developed beyond its natural state as open field, except for agricultural use as pasture for livestock. This site is a private office development and is not subject to adoption under a Section 104 agreement (Water Industry Act 1991 (1991)). 
Classed as 'greenfield', there is no contamination from previous industrial use, as might be found on a 'brownfield' site. The soil has average permeability and good bearing pressure values; the groundwater table is below any construction depth. Site topography is generally flat, with a gentle slope from north to south; as a greenfield location, there has been no previous development on site. However, both foul and surface water sewers run along the western boundary. These site conditions allow for an unbiased comparison of the two drainage systems; there are no obstructions in terms of design and layout for either type of system.

\section{System-specific design requirements}

\subsection{Conventional piped system}

Design needs for a piped system include a calculation of runoff rate and an appropriately sized pipe network to transport water flow off site. A number of physical devices have to be installed with this system to make it work, including an attenuation tank, petrol/oil interceptor and flow control device. Gullies and kerb drains are needed to pick up the surface water.

The runoff rate is one of the first calculations required when a development site is to be connected to a public sewer system and/or surface water is to be discharged to a watercourse. (An alternative to the runoff calculation is a flow rate set by the local water authority.) This flow rate off site is a key value, since it requires approval from the Environment Agency and usually becomes the post-development flow rate restriction and forms the basis for the size of attenuation tanks and specification of flow control devices.

For the purposes of this study, the flow rate was calculated using drainage systems design software. WinDes software (http://www.microdrainage.co.uk/) is the UK drainage and flood systems industry standard product: the data produced by this software will form the basis for the discussion and results in this paper. Simulation and source control were used to design each system, with the focus on a comparison of drainage methods rather than the software used.

The flow rate was calculated using the Interim Code of Practice (ICP) for Suds mean annual flood method (NSWG, 2004). The ICP for Suds stipulates that this method (from Marshall and Bayliss (1994)) is to be used for determining peak greenfield runoff rates. As the drainage system is required to withstand flooding from a 30-year storm event, this is the duration for which the flow rate was calculated. The software returned a value of $6 \cdot 3 \mathrm{1} / \mathrm{s}$ for a 30 -year event (see Figure 2).

The flow rate confirmed, layout and design of the pipe network can proceed; a suitable connection point to the public sewer near the site entrance is selected (see Appendix (Figure 10) for site layout) and a pipe layout designed that prioritises the shortest routes using the fewest number of pipes. Deep sump

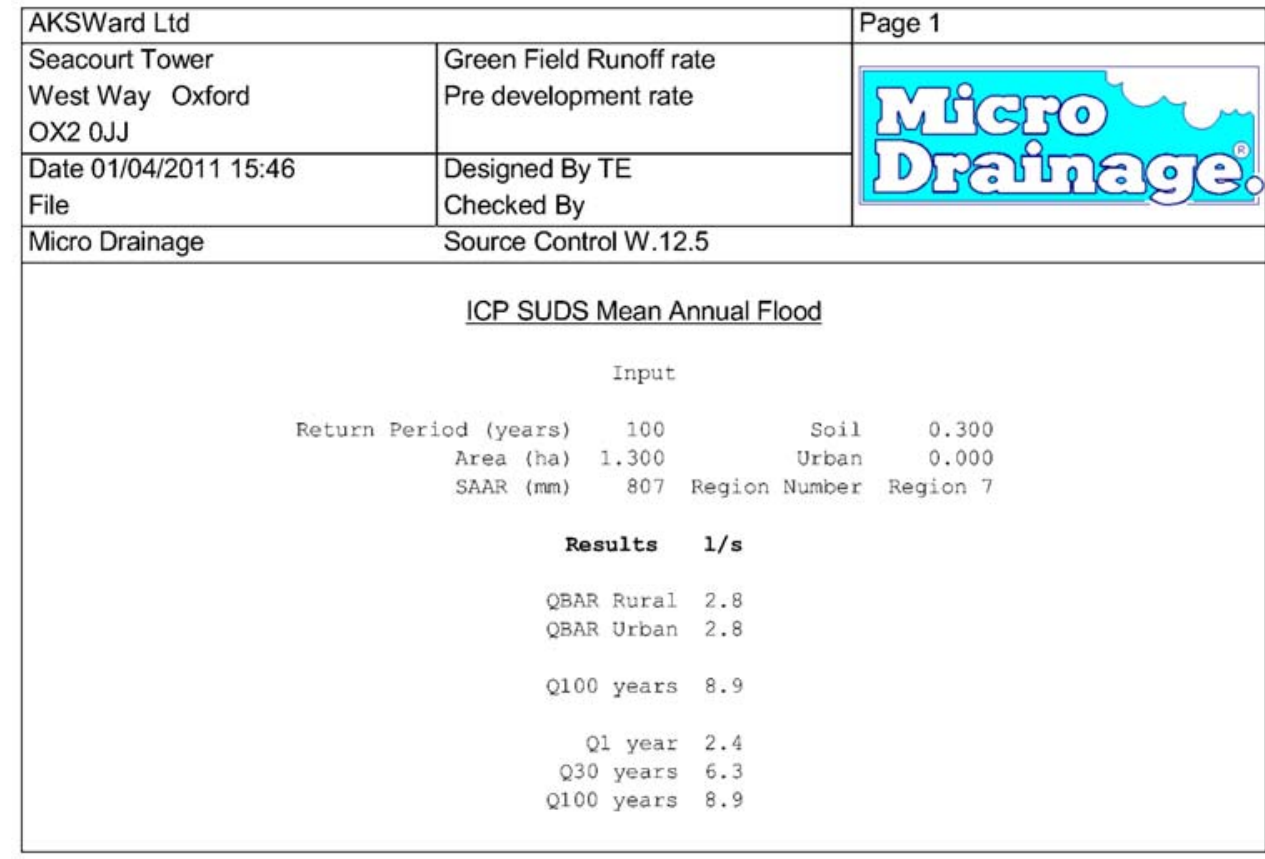

Figure 2. Mean annual flood calculation (NSWG, 2004) 
road gullies are used to drain most of the site, with roof drainage discharging via rainwater pipes into the piped system.

Catchpits (Figure 3) are used in place of manhole chambers where sub-networks connect to form the main pipe network. These catchpits, together with deep sump road gullies, help prevent the system from silting up over a period of time. The main entrance and roundabout are drained using kerb drains discharging to catchpits, connected in turn to the piped network (see Appendix (Figure 10)).

The size and dimensions of the car park mean that a petrol/oil interceptor is required. Document PPG3 (Environment Agency, 2006a) specifies that any car park with 50 spaces or more and/or exceeding an area of $800 \mathrm{~m}^{2}$ needs this unit, which must also include a warning system to alert users when contaminant levels reach specific levels and when it requires emptying.

A flow control device is required to limit the flow off site to the pre-development rate of $6 \cdot 3 \mathrm{l} / \mathrm{s}$. Use of a vortex control (Figure 4 ) creates a rotating flow around an opening, much as a domestic bath outflow reduces the flow rate even with water still to drain. The speed of the water flow around the periphery creates an air pocket in the core; back pressure from this reduces the discharge. This has the added benefit of lowering the volume of water to be retained in the attenuation tank.

The conventional piped system was modelled to calculate the size of the attenuation tank required and the size of pipes required in the network and to check the system would not flood for a 30-year storm event. (At this point if there is any flooding the system can be altered to remove the flood risk dependent on where the flooding occurs; a larger attenuation tank or larger pipe sizes may be required.) Having modelled the system and achieved zero flooding for the 30-year event and controlled flooding for the 100-year event, the system size and layout were complete. The results revealed that an attenuation tank of volume $153 \mathrm{~m}^{3}$ will be required, with pipe sizes ranging from $100 \mathrm{~mm}$ to $300 \mathrm{~mm}$ diameter and an appropriate size/ model of vortex control to achieve the off-site flow rate.

Traditional piped system requirements will typically comprise

pipes: $340 \mathrm{~m}$ of $100 \mathrm{~mm}$ diameter; $360 \mathrm{~m}$ of $150 \mathrm{~mm}$ diameter; $64 \mathrm{~m}$ of $225 \mathrm{~mm}$ diameter; $53 \mathrm{~m}$ of $300 \mathrm{~mm}$ diameter

- 46 road gullies

10 catchpits, $1200 \mathrm{~mm}$ diameter

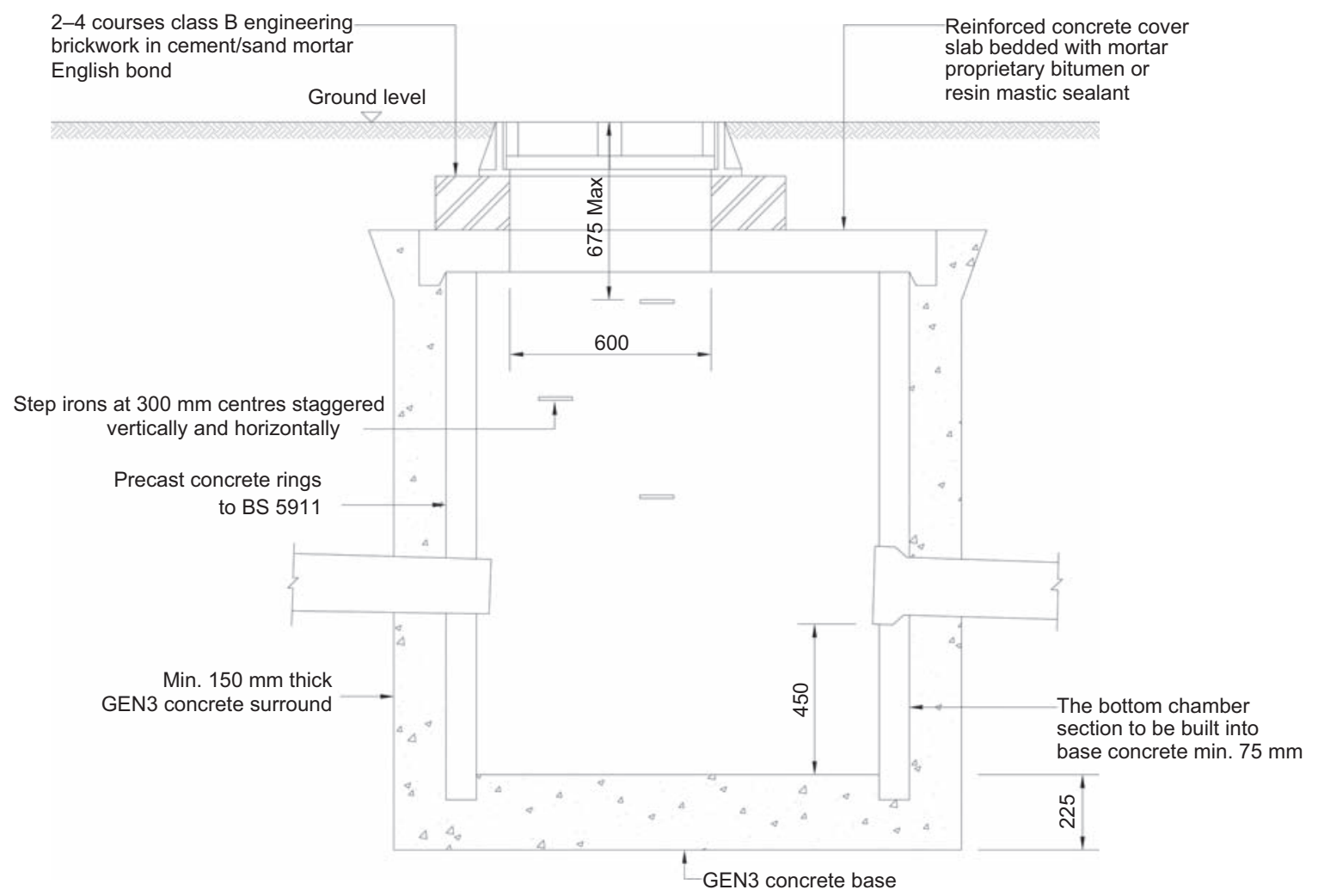

Figure 3. Typical catchpit detail (dimensions in $\mathrm{mm}$ ) 


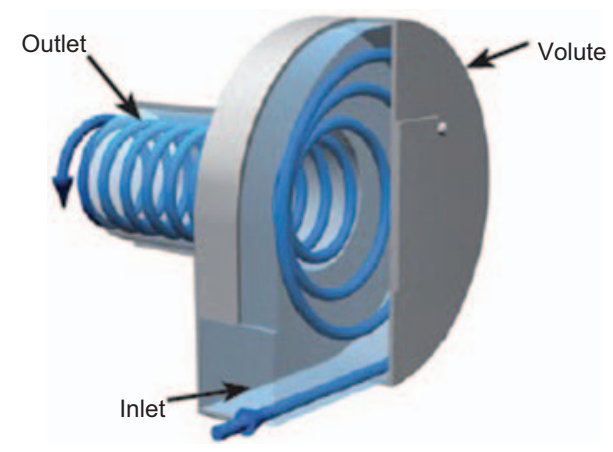

Figure 4. A vortex flow control

1 petrol interceptor

13 inspection chambers

- 1 vortex control and specialist chamber

average pipe depth $1 \mathrm{~m}$ to $1.5 \mathrm{~m}$

attenuation tank $153 \mathrm{~m}^{3}$

- Section 106 connection application to sewerage undertaker for connection to public sewer (Water Industry Act 1991 (1991))

- public sewer connection made within highway curtilage relevant permissions and fee required.

Figure 5 shows the flood flow for a 100-year event, with additional flooding from climate change (plus 30\% peak rainfall intensity under current best management practice) for the piped drainage system. There will be above-ground flood flow, but it will be contained by the car park kerbs and does not pose a risk to the buildings. There is a natural slope across the site from north to south (see Figure 5). The Suds system will experience a small amount of localised flooding near the soakaway for building B (see Appendix (Figure 10)); this will soak into the permeable paving locally, all other excess water from the storm event will be contained within the swale and pond.

\subsection{Suds}

Using Suds to move water away from the development involves substantial differences to conventional methods. As modelled using WinDes software, the soakage rate used was $0.05000 \mathrm{~m} / \mathrm{h}$ based on permeability rates in the region of sandy clays-sandy loams. This rate provides acceptable levels of infiltration without being classed as excellent (like gravel) or poor (such as clay). Soakage tests would be carried out in accordance with BRE Digest 365: Soakaway design (BRE, 1991).

The car park and roadways discharge to permeable paving and swales (under PPG3 no interceptor is required). A wet detention pond is used (which can be modelled in the used

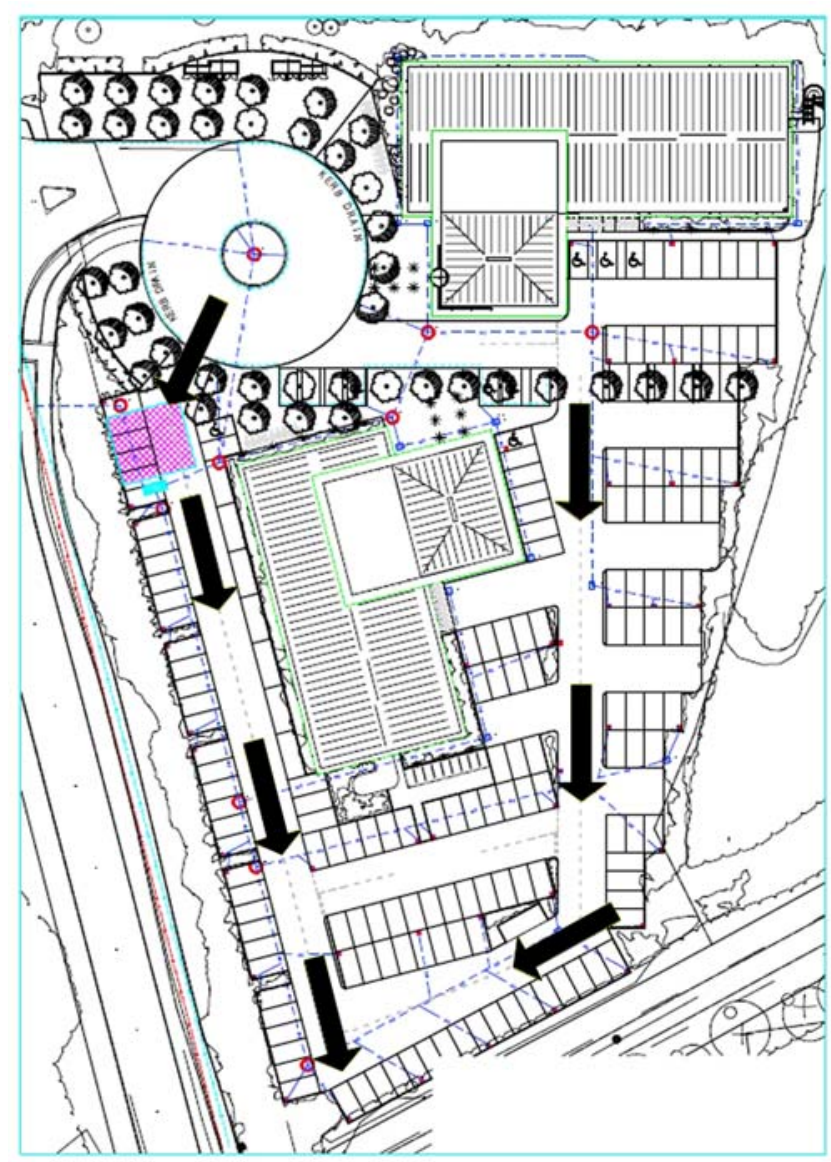

Figure 5. Flood flow paths for exceedance event

software) with the depth of permanent water approximately $500 \mathrm{~mm}$. The base and first $500 \mathrm{~mm}$ around graded sides are lined with an impermeable membrane to maintain the water body; the graded sides above this level remain unlined and act as infiltration for stormwater that enters the site.

Office B drains via pipes to this detention pond (see layout given in the Appendix (Figure 10)). Office A has a soakaway, as the pond is too far from this location. The main entrance and roundabout use kerb drains with an infiltration trench, while the western roads and car park drain out to a swale; the swale is connected to the wet detention pond. Most of the car park area and associated roads are drained via permeable paving. The road and car parking to the western edge of the site drain directly to a swale running north to south along the western boundary of the site. Although the swale takes up a $6 \mathrm{~m}$ wide swathe of land between car park and roadway, there is no loss of amenity to the site: this area is designated for landscaping under the conventional piped scheme (Figure 6). The greenfield location of this development makes this viable, where perhaps an existing urban site would require a different solution. 




Figure 6. Swale cross-section (dimensions in $\mathrm{mm}$ )

Kerb drains are used for the main entrance and roundabout, the difference from a conventional piped system being that water flow discharges into an infiltration trench running parallel with the kerbs. The conventional system also required a petrol interceptor due to the size of the car park; as noted above, under PPG3 (Environment Agency, 2006a) the interceptor is not required in a Suds scheme as the use of permeable paving, swales and detention ponds are proven methods of breaking down impurities and chemicals from surface runoff.

The swale eventually discharges into the wet detention pond located at the south-west corner of the site. Building B water runoff is routed by way of rainwater pipes into a piped system that terminates at an open outfall to the detention pond. The location of building A means it is too far from the pond to use a piped connection - a soakaway is used instead (Figure 7). Between the building and soakaway, a catchpit is installed to reduce the amount of silt and debris reaching the soakaway. A catchpit is also needed before the outfall to pond from building B.

Where the piped drainage system uses conventional block paving as hard surfacing to the parking bays, this is replaced with permeable block paving for the Suds design (Figure 8). The adjoining roads and hardstanding areas drain onto this permeable paving.

With the layout complete and all the hardstanding accounted for, the system can be modelled in WinDes to calculate the sizes of the various infiltration systems. The calculations show that the requirements are a pond of $130 \mathrm{~m}^{3}$, pipe sizes ranging from $100 \mathrm{~mm}$ to $150 \mathrm{~mm}$, a soakaway of $67 \mathrm{~m}^{3}$, with a swale $88 \mathrm{~m}$ long, $6 \mathrm{~m}$ wide and $0.4 \mathrm{~m}$ deep. The Suds system requirements are

pipes: $125 \mathrm{~m}$ of $100 \mathrm{~mm}$ diameter; $137 \mathrm{~m}$ of $150 \mathrm{~mm}$ diameter

- 2 catchpits

13 inspection chambers

average pipe depth $1 \mathrm{~m}$

- wet detention pond $160 \mathrm{~m}^{3}$

- swale $(L \times B \times D) 88 \mathrm{~m} \times 6 \mathrm{~m} \times 0.4 \mathrm{~m}$

soakaway $67 \mathrm{~m}^{3}$

permeable block paving infiltration trenches $(L \times B \times D)(156 \mathrm{~m} \times 0.6 \mathrm{~m} \times$ $0 \cdot 6 \mathrm{~m})$

- no off-site surface water drainage connection required

no requirement for petrol interceptors

loss of six parking spaces to allow for wet detention pond (Figure 10).

\section{System comparisons}

From the outset, prior to any design or calculation taking place, there are immediate ecological and economic benefits to the Suds approach. PPG3 specifies a petrol/oil interceptor for any car park larger than $800 \mathrm{~m}^{2}$ or with more than 50 spaces. The use of permeable paving and swales will meet the criteria of pollution prevention without the cost of an interceptor. Some of the drainage components are required for both schemes (the pipe networks serving rainwater pipes for each building and the kerb drains at the main entrance) and these are therefore cost neutral.

To ensure a fair comparison between the drainage systems, the site layout was unchanged for both designs. The external paving design was retained as much as possible for both conventional and Suds systems. The only noticeable change to the layout is the loss of six parking spaces in the Suds design. Where block paving is used for the parking spaces in the conventional system, the permeable paving is limited to the same areas, with the road surface unchanged for both designs.

The outcome of the Suds design was zero off-site surface water flow; in contrast the traditional system was limited from a flow of $149 \mathrm{l} / \mathrm{s}$ to the greenfield runoff rate of $6 \cdot 3 \mathrm{l} / \mathrm{s}$. This creates the requirement for both an attenuation tank $\left(153 \mathrm{~m}^{3}\right.$ volume $)$ and a flow control device. Although the Suds system does not connect to the public sewer system, it does require land in order to achieve its zero off-site flow rate through infiltration. The wet detention pond has been sized such that it takes up as little development land as possible. It is the size of the pond that causes the net loss of six parking spaces (from the original total of 158). PPG13 (DCLG, 2011) specifies a maximum parking standard of one space per $30 \mathrm{~m}^{2}$ gross floorspace for office developments above $2500 \mathrm{~m}^{2}$ - using a travel and access plan to encourage use of public transport and the environmental benefits of the detention pond should offset the loss of parking. This paper looks to utilise multiple cost-effective Suds techniques and discuss the pros and 


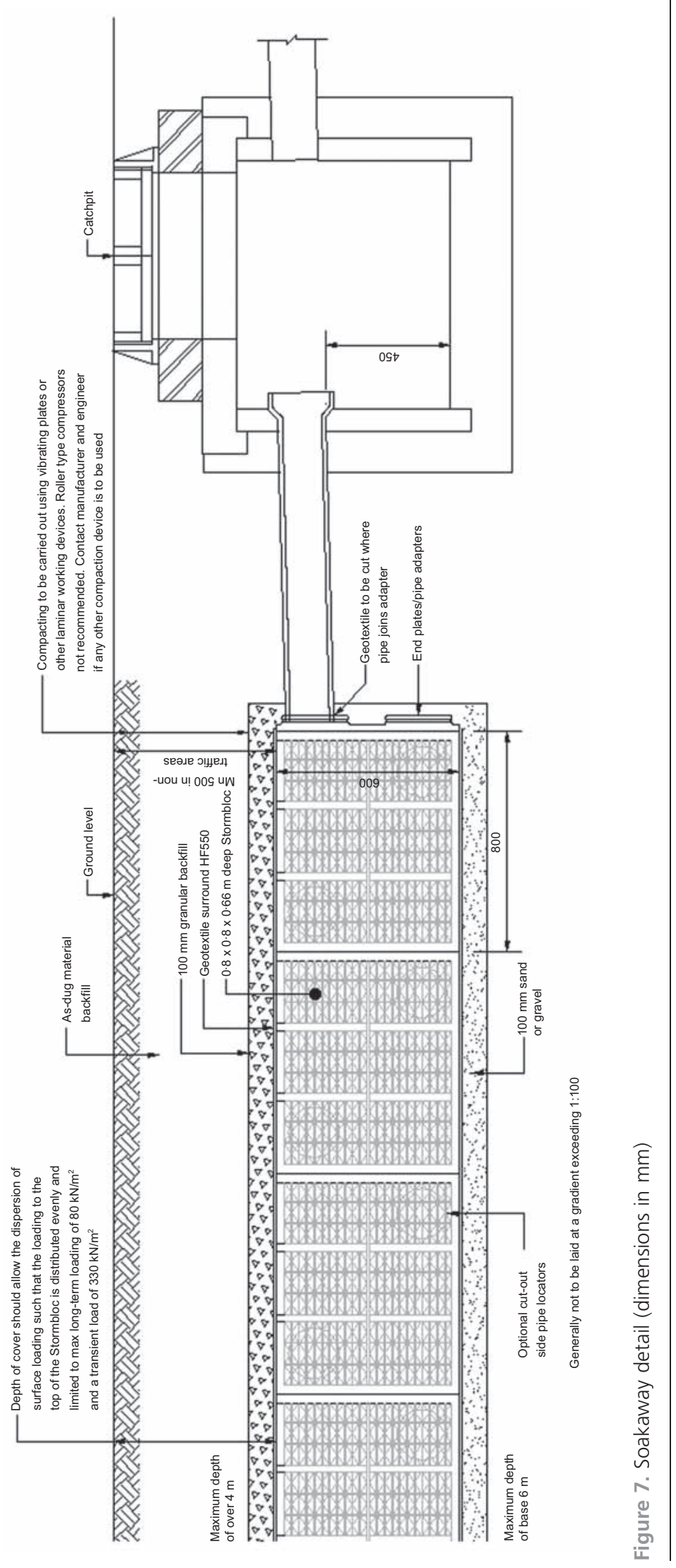




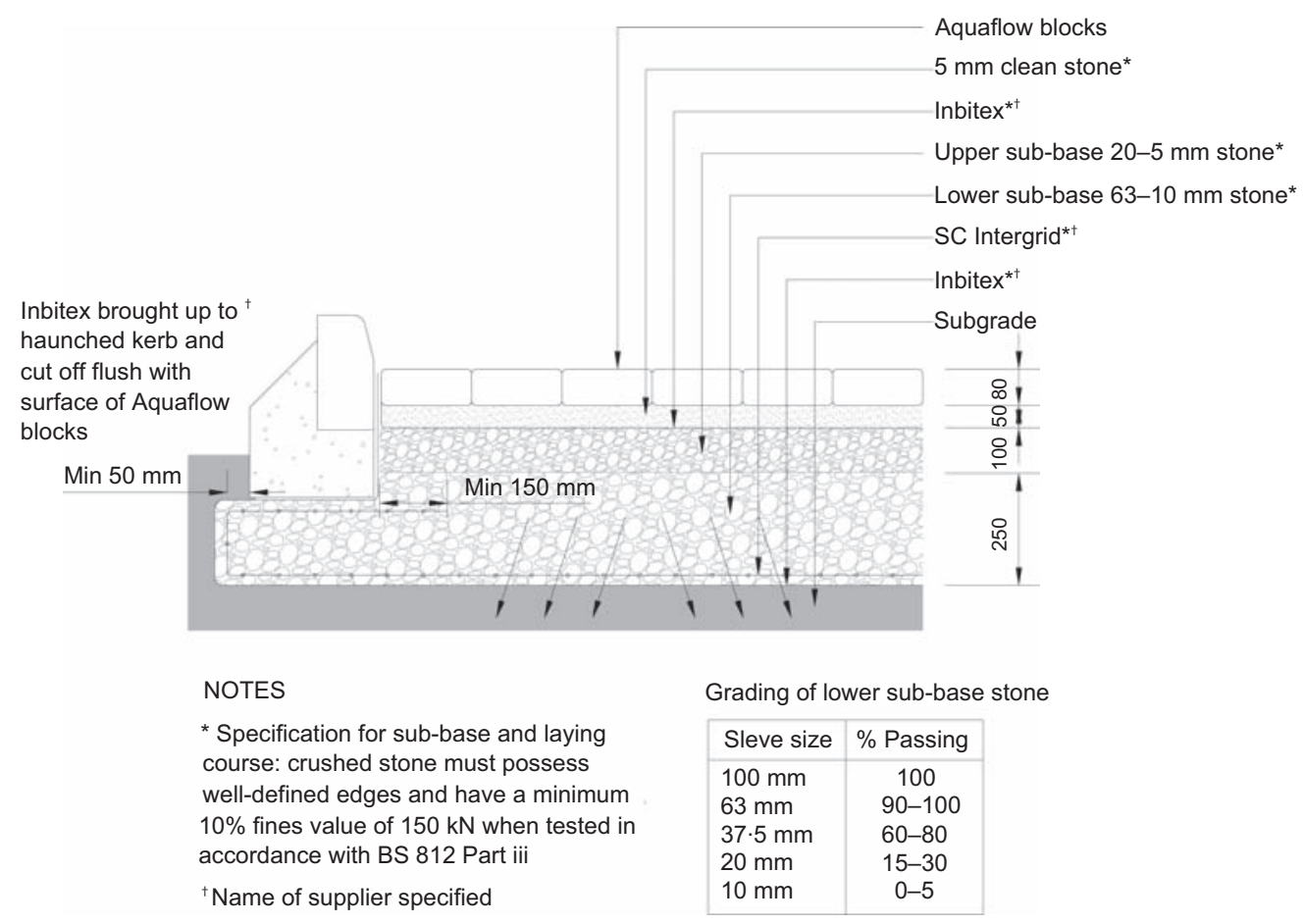

Figure 8. Permeable paving detail (dimensions in $\mathrm{mm}$ )

cons of each. While the parking spaces could be preserved by using a below-ground storage system, a pond was selected as it offers excellent storage for the more extreme storm events when combined with the swale.

Comparing the costs of the two systems in the longer term is difficult: the maintenance required of conventional pipe

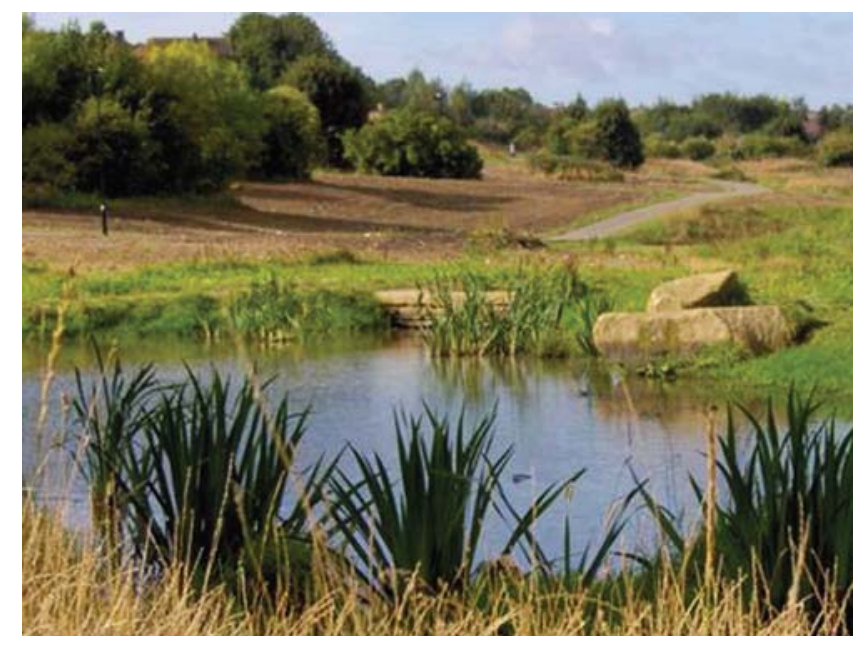

Figure 9. Example of a wet detention pond (CCC, 2009) systems is not the same as that for swales and ponds. Research undertaken by Duffy et al. (2008) on maintenance of a sustainable drainage scheme over 5 years at the Dunfermline eastern expansion (DEX) development produced an average annual cost 20-25\% lower than a conventional drainage system.

The difference in whole-life costs of traditional block paving as against permeable block paving is negligible under good soil conditions according to Interpave, the Precast Concrete Paving and Kerb Association (Stoddart, 2006), and is treated as cost neutral in this review.

\section{Conclusion}

This sample site would be restricted to the greenfield runoff rate. One of the aims of Suds design, however, is to have zero off-site surface water flow. This refers to the site not being connected to a sewer system or watercourse; all floodwater will remain on site (within the pond, swale and car park bounded by kerbs) until it permeates into the ground. More to the point, there is no infrastructure charge or annual discharge fees. Additional cost savings already mentioned include the lack of any petrol/oil interceptors for Suds systems.

The introduction of swales and wet detention ponds to development sites enhances the amenity value for people and wildlife. The 'natural' landscape is an asset for both developers 
and buyers of commercial property, since each can use the 'green' environment as a selling point to companies and employees. The benefit to the environment is less obvious to the naked eye, but the fact is that surface water flow is being filtered before soaking into the ground and ultimately recharging groundwater resources.

To drain the main entrance area, the Suds design uses mainly recycled aggregates to form the infiltration trenches. These materials can be as simple as graded demolition rubble from crushed bricks and concrete. In contrast, the piped network requires more precision and quality of materials to meet system requirements, as well as the need for inspection chambers and catchpits. Note that the buildings still require pipework to drain roof water for the Suds design.

The conventional system has a large piped network with catchpits, gullies and chambers plus the cost of installing an

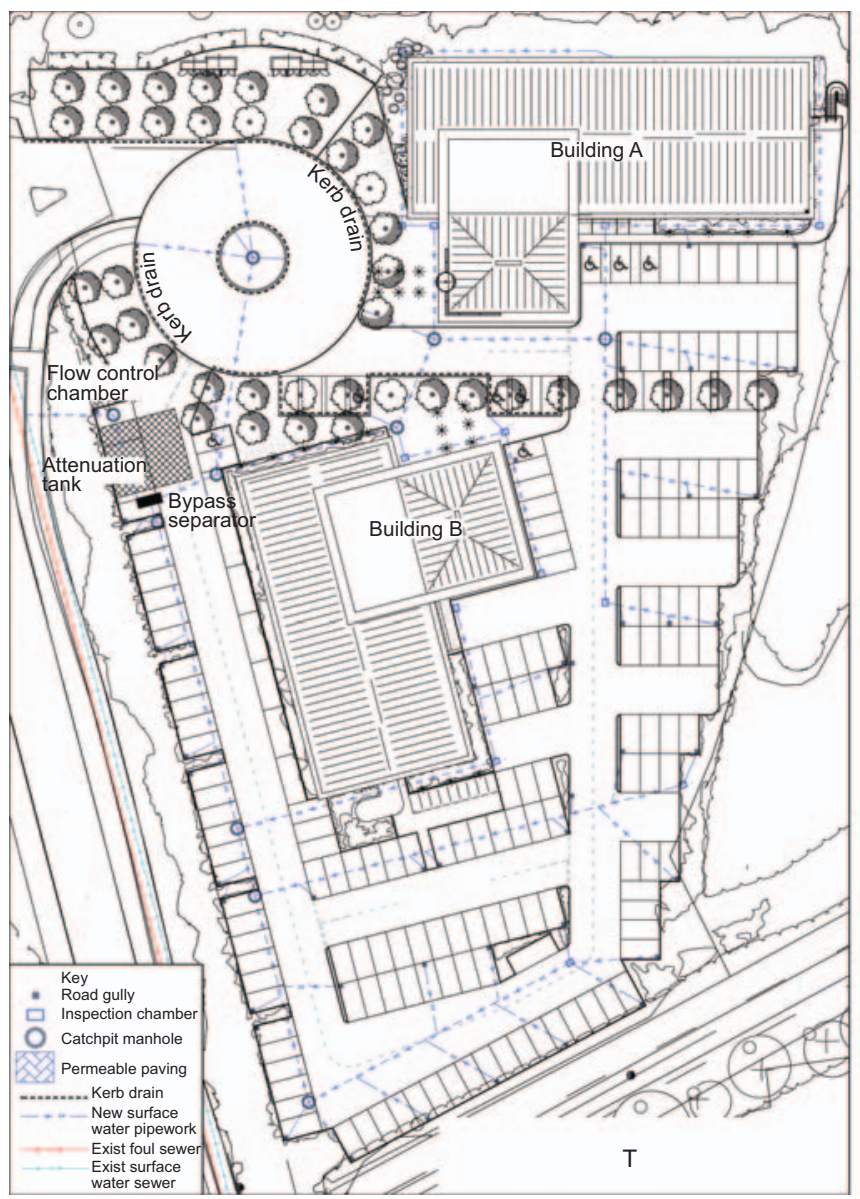

(a) attenuation tank and flow control device. These require quality manufactured components, precision installation and wellgraded bedding materials. By comparison, the detention pond and swale are essentially little more than excavated depressions on site. The complexity of installation for the piped system has both cost and scheduling implications during site development.

A caveat to this summary: the data for this paper come from a software simulation package. As such, only a physical project can verify the results supplied, and also the operation and maintenance costs in the longer term. The authors hope to publish a second paper that investigates just such a project.

The conclusion is that the sustainable system is simpler than the piped design and likely to be the cheaper system to install. In addition, the Suds option scores on all environmental counts, to the benefit of flora, fauna and groundwater supplies.

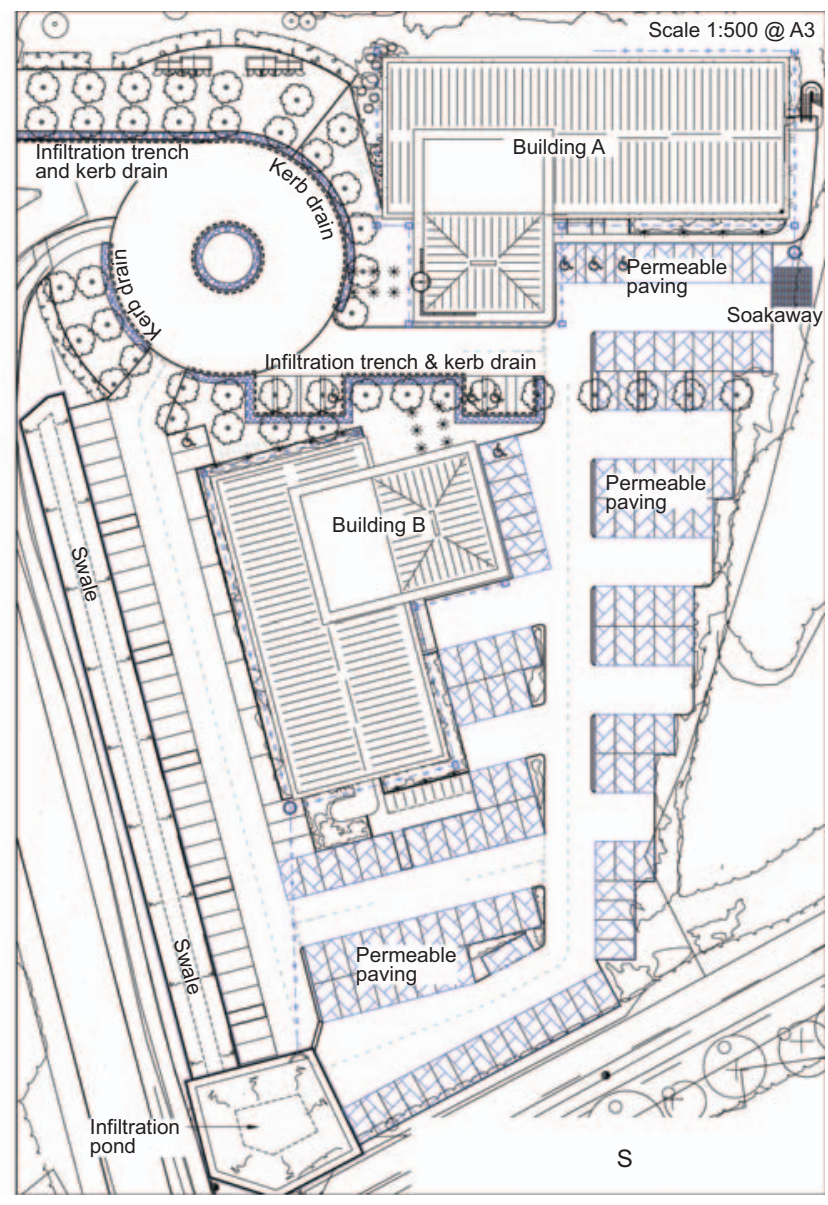

(b)

Figure 10. Site drainage layout for (a) a traditional piped system and (b) a sustainable drainage scheme 
Arguably one of the downsides to development in the UK is the effect it has on downstream flooding and habitats. This is one of the reasons why the government is emphasising Suds design and, with the right Suds solutions chosen, there need not be a requirement for extra cost or land loss to achieve a successful result.

\section{Appendix}

Figure 10 shows site layout drawings for sustainable and traditional piped drainage systems.

\section{REFERENCES}

BRE (Building Research Establishment) (1991) BRE Digest 365: Soakaway Design. Building Research Establishment, Garston, UK.

CCC (Cambridge City Council) (2009) Sustainable Drainage: Cambridge Design and Adoption Guide. CCC, Cambridge, UK.

CIRIA (Construction Industry Research and Information Association) (2000) Research Project 555. Sustainable Urban Drainage Systems - Design Manual for England and Wales. CIRIA, London, UK, Report C522.

DCLG (Department of Communities and Local Government) (2006) Planning Policy Statement 25: Development and Flood Risk. The Stationery Office, London, UK.

DCLG (2011) Planning Policy Guidance 13: Transport. The Stationery Office, London, UK.

Duffy A, Jefferies C, Waddell G et al. (2008) A cost comparison of traditional drainage and Suds in Scotland. Water Science and Technology 57(9): 1451-1459.

Environment Agency (2003) Sustainable Drainage Systems (Suds) - An Introduction. Environment Agency, Bristol, UK.

Environment Agency (2006a) Pollution Prevention Guidelines: Use and Design of Oil Separators in Surface Water Drainage Systems: PPG3. Environment Agency, Bristol, UK.

Environment Agency (2006b) Underground, Under Threat. Groundwater Protection: Policy and Practice. Part 1 - Overview. Environment Agency, Bristol, UK.

European Union (2000) Directive 2000/60/EC of the European Parliament and of the Council of 23 October 2000 establishing a framework for Community action in the field of water policy. Official Journal of the European Union L327/43.

Flood and Water Management Act 2010 (2010) Elizabeth II. Chapter 29. The Stationery Office, London, UK.

Jones J (2008) Flood risk assessments and the planning sector. British Hydrological Society 10th National Hydrology Symposium, Exeter, UK, pp. 317-320.

Marshall DCW and Bayliss AC (1994) Flood Estimation for Small
Catchments. Institute of Hydrology, Wallingford, UK, Report 124.

May R and Kellagher R (2004) Drainage of Development Sites $A$ Guide. Construction Industry Research and Information Association with HR Wallingford Limited, London, UK, Report CIRIA X108.

NSWG (National Suds Working Group) (2004) Interim Code of Practice for Sustainable Drainage Systems: Framework Document. Office of the Deputy Prime Minister,

Department for Environment, Food and Rural Affairs and Construction Industry Research and Information Association with others, London, UK.

ODPM (Office of the Deputy Prime Minister) (2002) The Building Regulations 2000. Approved Document H: Drainage and Waste Disposal. ODPM, NBS/RIBA Enterprises, London, $\mathrm{UK}$.

ODPM (2005) Planning Policy Statement 9: Biodiversity and Geological Conservation. The Stationery Office, London, UK.

Stoddart S (2006) The Costs of Paving. Comparative Initial Construction and Whole Life Cost Analyses for Pavements. Uniclass L535:L217. Interpave, The Precast Concrete Paving and Kerb Association, Leicester, UK.

Taylor P (2003) Groundwater - Urgent Action Needed. See http://www.water.org.uk/home/about/water-uk-team/chiefexecutive-speeches/groundwate-110703-1?textonly =false (accessed 25/06/2012).

UK Government (1994) Biodiversity: The UK Action Plan. (Cm 2428) Her Majesty's Stationary Office, London, UK.

Water Industry Act 1991 (1991) Elizabeth 11. Chapter 56. Her Majesty's Stationary Office, London, UK.

WRc plc (2006) Sewers for Adoption - A Design and Construction Guide for Developers, 6th edn. WRc plc, Swindon, UK.

Woods Ballard B, Kellagher R, Martin P et al. (2007) The Suds Manual. Construction Industry Research and Information Association, London, UK, Report C697.

\section{WHAT DO YOU THINK?}

To discuss this paper, please email up to 500 words to the editor at journals@ice.org.uk. Your contribution will be forwarded to the author(s) for a reply and, if considered appropriate by the editorial panel, will be published as discussion in a future issue of the journal.

Proceedings journals rely entirely on contributions sent in by civil engineering professionals, academics and students. Papers should be 2000-5000 words long (briefing papers should be 1000-2000 words long), with adequate illustrations and references. You can submit your paper online via www.icevirtuallibrary.com/content/journals, where you will also find detailed author guidelines. 